$$
\begin{aligned}
& \text { بررسى شاخص هاى بيوشيميايى گَياه دارويى بادرشبو تحت اثر نانوذره مس و : بلاسماى } \\
& \text { سرد اتمسفرى }
\end{aligned}
$$

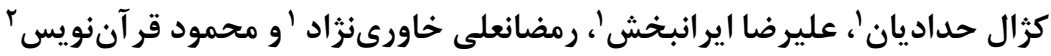

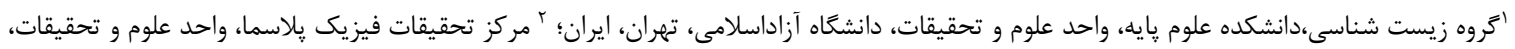

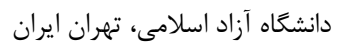

$$
\begin{aligned}
& \text { مسئول مكاتبات: عليرضا ايرانبخش، iranbakhsh@iau.ac.ir }
\end{aligned}
$$

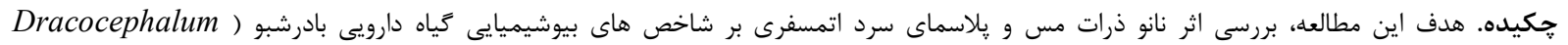

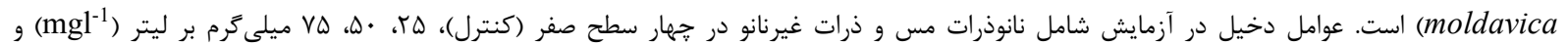

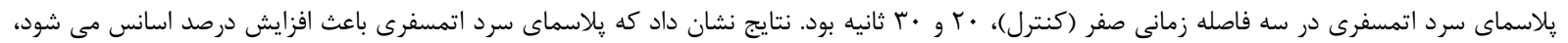

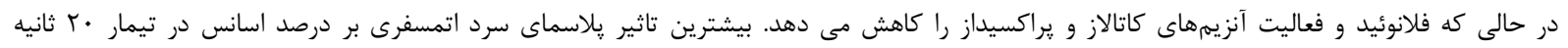

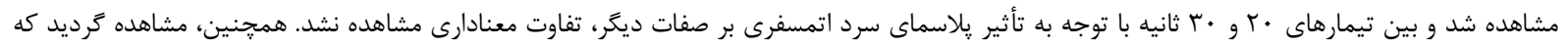

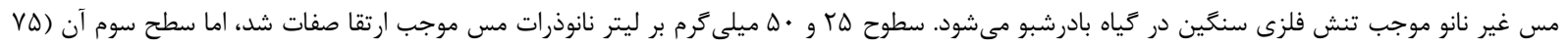

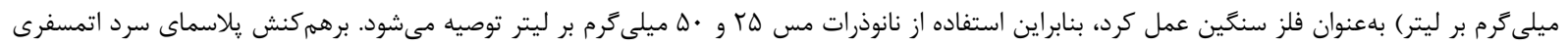

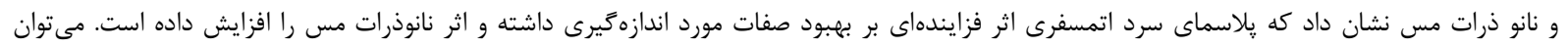

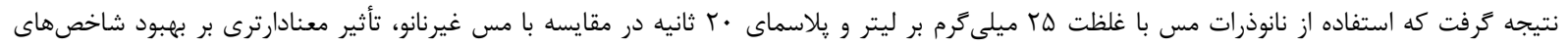

$$
\text { بيوشيميايى كياه بادرشبو دارد. }
$$

$$
\text { وازه هاى كليدى. يراكسيداز، درصد اسانس، فلانوئيد، كاتالاز، نعناييان }
$$

\title{
The effects of copper nanoparticles and cold atmospheric plasma on biochemical indices of Dracocephalum moldavica
}

\section{Kazhal Haddadian', Alireza Iranbakhsh ${ }^{1}$, Ramazan Ali Khavari Nejad ${ }^{1}$ \& Mahmood $^{1}$ Ghorannevis $^{2}$}

${ }^{1}$ Department of Biology, Faculty of Science, Science and Research Branch, Islamic Azad University, Tehran, Iran; ${ }^{2}$ Plasma Physics Research Center, Science and Research Branch, Islamic Azad University, Tehran, Iran Corresponding author: AlirezaIranbakhsh, iranbakhsh@iau.ac.ir

\begin{abstract}
The Moldavian dragonhead (Dracocephalum moldavica L., Lamiaceae) is an annual medicinal plant with beneficial nutritional sources that plays important roles in human and animal feed. Nanoparticles and cold atmospheric plasma increase biochemical compounds in plants. In this study, the effects of copper nanoparticles and cold atmospheric plasma on biochemical indices of the medicinal plant Dracocephalum moldavica were investigated. Moldavian dragonhead plants were subjected to four doses of copper nanoparticles $\left(0,25,50\right.$ and $\left.75 \mathrm{mgl}^{-1}\right)$ and cold atmospheric plasma at three durations (zero, 20 and $30 \mathrm{~s}$ ). The results showed that cold atmospheric plasma significantly increases the essential oil percentage, while it decreases the amount of flavonoid content and activity of catalase and peroxidase enzymes. Cold atmospheric plasma (20 s) showed significant positive impact on essential oil content, while different time duration $(20$ and $30 \mathrm{~s})$ did not show a significant impact on other traits. Lower doses of copper nanoparticles $\left(25\right.$ and $50 \mathrm{mgl}^{-1}$ ) showed positive impacts on measured traits, while $75 \mathrm{mgl}^{-1}$ dose negatively affected the measured traits and functioned as a heavy metal. The cold atmospheric plasma and copper nanoparticles interactions indicated that cold atmospheric plasma had an incremental effect on the improvement of measured traits and increased the effect
\end{abstract}


of copper nanoparticles. In conclusion, the results showed that copper nanoparticles with $25 \mathrm{mgl}^{-1}$ dose along with cold atmospheric plasma with $20 \mathrm{~s}$ duration had significant positive effects on the improvement of biochemical indices of Dracocephalum moldavica.

Keywords. catalase, essential oil percentage, flavonoids, Lamiaceae, peroxidase

\section{INTRODUCTION}

Dracocephalum moldavica L. is an annual herbaceous plant, belongs to Lamiaceae family, and capable of growing almost in any climate. The distillate of $D$. moldavicais used as an anti-epileptic drug, stomach enhancer, digestive facilitator, and for treating cardiac arrhythmias (Abd El-Baky\&ElBaroty, 2008). This plant has many applications in traditional and modern medicine and is used to treat dyspepsia, abdominal bloating and stomach upset. In addition, it is used in the food industries such as beverage industry, sanitary and cosmetic industries (Hussein et al., 2006).

The absorption of carbon and metal nanomaterials by plants is a new field of research. Absorption, displacement and accumulation of nanoparticles vary depending on species, the type and size of chemical composition, the structure and strength of nanoparticles (Rico et al., 2011). Recently, many studies have been conducted on the severe toxicity of nanoparticles and their positive and negative effects on plants (Menard et al., 2011).

Nanoparticles are atoms or molecules with dimensions ranging from 1 to $100 \mathrm{~nm}$, and can change their physical and chemical properties in comparison to coarse particles. Nanoparticles can be made of a wide variety of coarse particles, and their performance depends on their chemical composition, and their size or shape (Monica \& Cremonini, 2009). In a study in the context of Canada, it was found that using nano-fertilizers could prevent a 2000-million-dollar loss, indicating higher utilization efficiency of nano-fertilizers compared to non-nanoscale fertilizers (Monreal, 2010). The nanoparticles mainly exist in soil and find a way to water. Information about the fate of nanoparticles in soil is limited, but it may enter the food chain and ultimately accumulate in the body of organisms. Plants are an important part of the environment and are considered as a potential route for transferring nanoparticles to food chain (Zhu et al., 2008; Asgari et al., 2018).

Nanotechnology is gradually transitioning from the experimental stage to practical and operational stage, and this will lead to a more tangible presence of this technology in agriculture (Baruah \& Dutta, 2009). The effect of nanoparticles on plants largely depends on their composition, concentration, size, and physical and chemical properties (Shalaby et al., 2016). Copper is an important element for the growth and development of plants; and plays a major role in the processes of protein and carbohydrate synthesis (Olszewska et al., 2008). Important characteristics of copper are high catalysis and electrical conductivity (Chandra et al., 2014). Application of CN10 to $30 \mathrm{mgl}^{-1}$ in soil has increased the growth and yield of wheat (Hafeez et al., 2015). Heavy metal stress causes lipid peroxidation, damage to the membrane, excessive production of hydrogen peroxide, and protein degradation (Manikandan et al., 2016). However, plants activate a series of antioxidant enzymes such as superoxide dismutase, catalase, peroxidase and ascorbate peroxidase to overcome the active oxygen species (Manikandan et al., 2015).

Catalase and peroxidase are also metalloenzymes, which repel the superoxide ion destruction effect. These enzymes provide a defensive system for the survival of aerobic organisms (Pandey et al., 2009; Posmyk et al., 2009). It has been found that copper oxide nanoparticles (CN) in Lemna minor reduced the growth while increased the activity of superoxide dismutase enzymes, catalase, peroxidase, and malondialdehyde (Song et al., 2016).

Plasma is a radiation flash which is very reactive. Chemical species such as charged particles, free radicals and some rays occur with electrical discharge while in contact with gas are called 'clod atmospheric plasma' and are produced under mild conditions (Fernández \& Thompson, 2012). Plasmaactivated water (PAW) increases the germination rate of radish seeds by up to $80 \%$ and improves bud burst in comparison with normal water. Plasma treatment improved seed germination and seedling growth. Although the effect of plasma discharge on the surface of wet seeds is rarely studied, the water molecules absorbed by the seed skin can react with plasma discharge and produce active species, consequently, the germination and bud burst can be highly influenced (Sivachandiran \& Khacef, 2017).

The positive effects of osmotic plasma on disinfection, breaking seed dormancy, seed germination, and root and stem growth have been reported in the bean, as it accelerates germination and breaking seed dormancy and increases the length of the roots and stems (Bormashenko et al., 2015). Cold atmospheric plasma (CAP hereafter) treatment exerts a positive effect on seed germination, growth, and yield of radish, accelerating these processes (Mihai et al., 2014). 

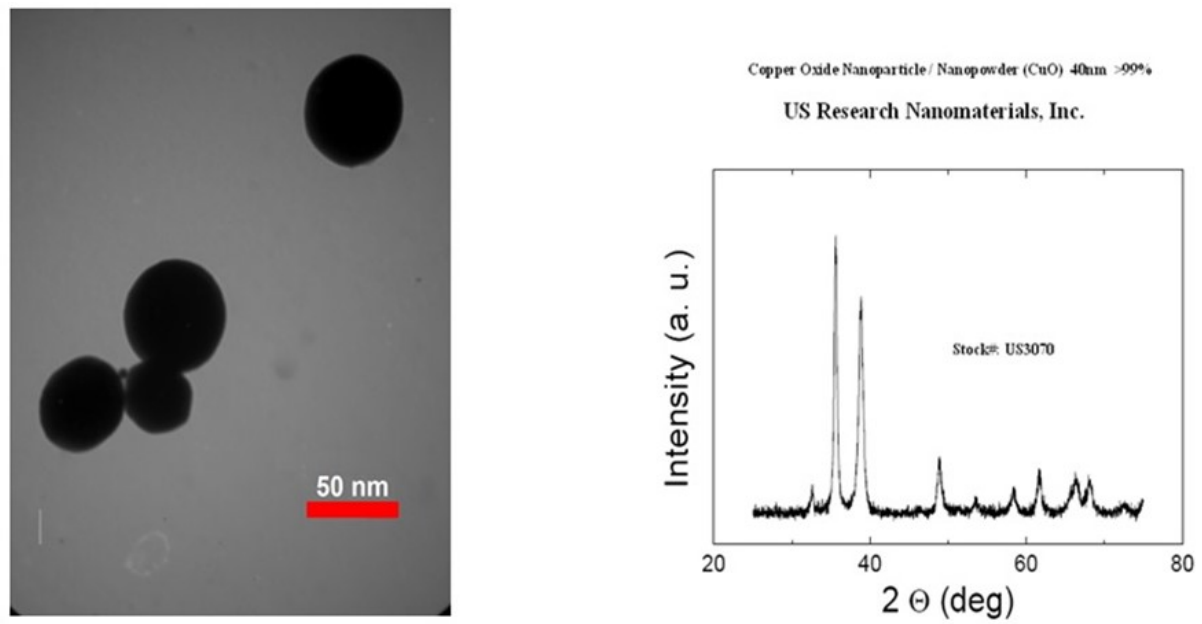

Figure 1. Transmission electron microscope photograph of copper nanoparticle and Zeta potential of $\mathrm{CuO}$ nanoparticles.

The application of CAPcan improve the metabolism and physiological properties of the plant, such as dehydrogenase activity, superoxide dismutase (Meiqiang et al., 2005), peroxidase (Jiang et al., 2014), photosynthetic pigments, photosynthesis efficiency, and nitrate reductase activity (Wu et al., 2007).

In our previous study, the effects of copper oxide nanoparticles and cold atmospheric plasma on $D$. moldavica were investigated and an increase in the height of aerial parts, the dry weight of aerial parts, protein percentage and a decrease in proline levels were observed (Haddadian et al., 2017). aim of the present study was to investigate the effects of $\mathrm{CN}$ and CAP on biochemical indices of D. moldavica $\mathrm{L}$. and providing practical solutions for the development of medicinal plants cultivation, especially $D$. moldavica L.

\section{MATERIALS AND METHODS}

The CuO NPs were purchased from NANOSANY Company, Mashhad, IRAN with a purity of $99 \%$, particle size of $>40 \mathrm{~nm}$. The morphology of the $\mathrm{CuO}$ nanoparticles was examined using transmission electron microscopy (TEM, JEOL, 100 CX, Japan) (Fig. 1).

This study was a randomized full-factorial design with four replications. The factors included the copper nanoparticles ( $\mathrm{CN}$ hereafter) and the nonnanoscale particles (NNC hereafter) at four levels of zero (control), 25, 50 and $75 \mathrm{mgl}^{-1}$ and cold atmospheric plasma (CAP hereafter) at three durations of zero (control), 20 and $30 \mathrm{~s}$. The required seeds were provided from Ahvaz Seed and Plant Research Center. The seeds were disinfected in $5 \%$ sodium hypochlorite solution for $5 \mathrm{~m}$. The culture medium was 1-liter pots filled with $55 \%$ Cocopeat and $45 \%$ perlite. The pots were irrigated daily with $100 \mathrm{ml}$ of Hoagland solution. Using the $\mathrm{CN}$ and $\mathrm{NNC}$ oxide took 90 days, i.e. 1 time per 72 $\mathrm{h}$. The temperature of greenhouse was about 29-32 ${ }^{\circ} \mathrm{C}$ during the day and about $20-25{ }^{\circ} \mathrm{C}$ at night. Then the plants were harvested after three month from cultivation-time. The $\mathrm{CN}$ was provided from the Iranian Nanomaterials Pioneers Company.Two groups of seeds were selected and exposed to Argon for 20 and $30 \mathrm{~s}$ in the form of radiation. The Baker and Nogues method was adopted to determine the total content of flavonoids. To measure the activity of catalase after extracting the protein, $2.5 \mathrm{ml}$ of 50 $\mathrm{mM}$ phosphate buffer $(\mathrm{pH}=7)$ and $.3 \mathrm{ml}$ of $3 \%$ hydrogen peroxide were mixed with $.2 \mathrm{ml}$ of the enzyme extracts in an ice bath, and the absorbance changes were read at the wavelength of $530 \mathrm{~nm}$ after $2 \mathrm{~m}$ (Aebi, 1984). Peroxidase (POD) activity was determined using the method of Kar and Mishra (1976), briefly, protein extract, $2 \mathrm{ml}$ of $100 \mathrm{mMTris}$ buffer $(\mathrm{pH}=7), .3 \mathrm{ml}$ of $5 \mathrm{mM}$ hydrogen peroxide, and $.2 \mathrm{ml}$ of $10 \mathrm{mM}$ Pyrogallol were mixed with 50 $\mu l$ of the enzyme extract in an ice bath, and the absorbance changes were measured at the wavelength of $450 \mathrm{~nm}$ after $2 \mathrm{~m}$ (Kar \& Mishra 1976). To calculate the percentage of essential oil, a 5 -g specimen was prepared from young twigs of each experimental unit and was extracted with a Clevenger-based distillation method. Analysis of Variance (ANOVA) was conducted with SAS, and mean comparison was run by Duncan at the probability level of $1 \%$.

\section{RESULTS}

\section{Flavonoid}

The results of ANOVA (Table 1) showed that CAP, $\mathrm{CN}$ and their interaction had significant effects on flavonoid $(\mathrm{p}<0.01)$. 


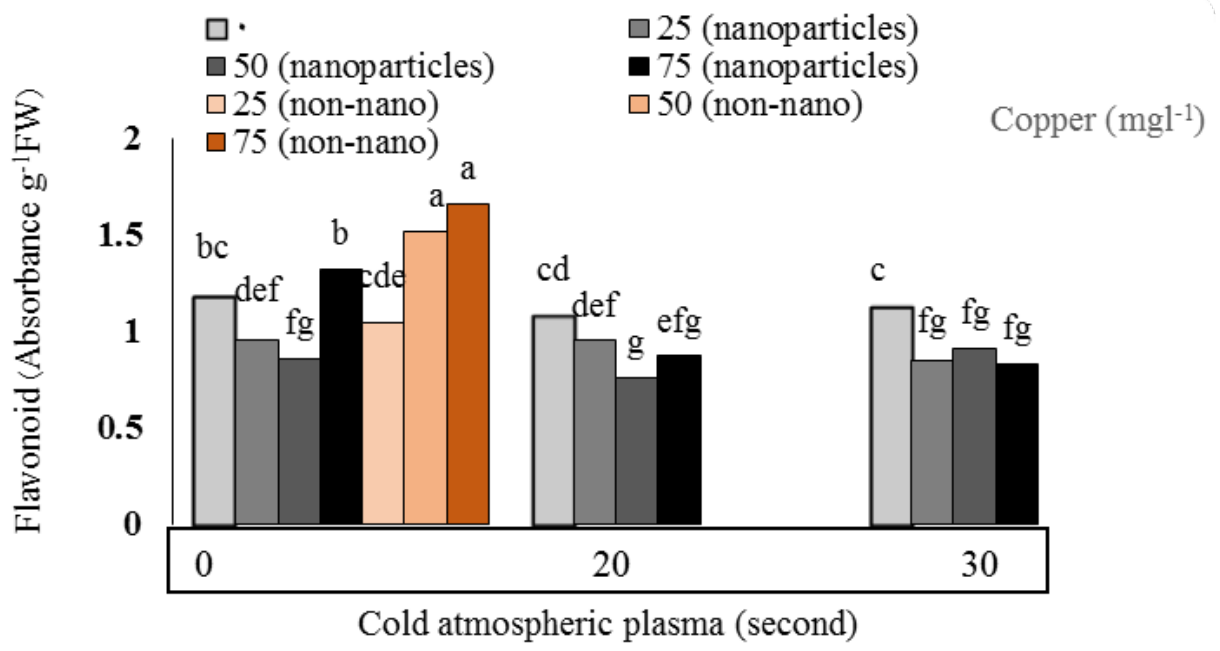

Figure 2. Investigating flavonoids under the influence of various levels of CAP and copper.

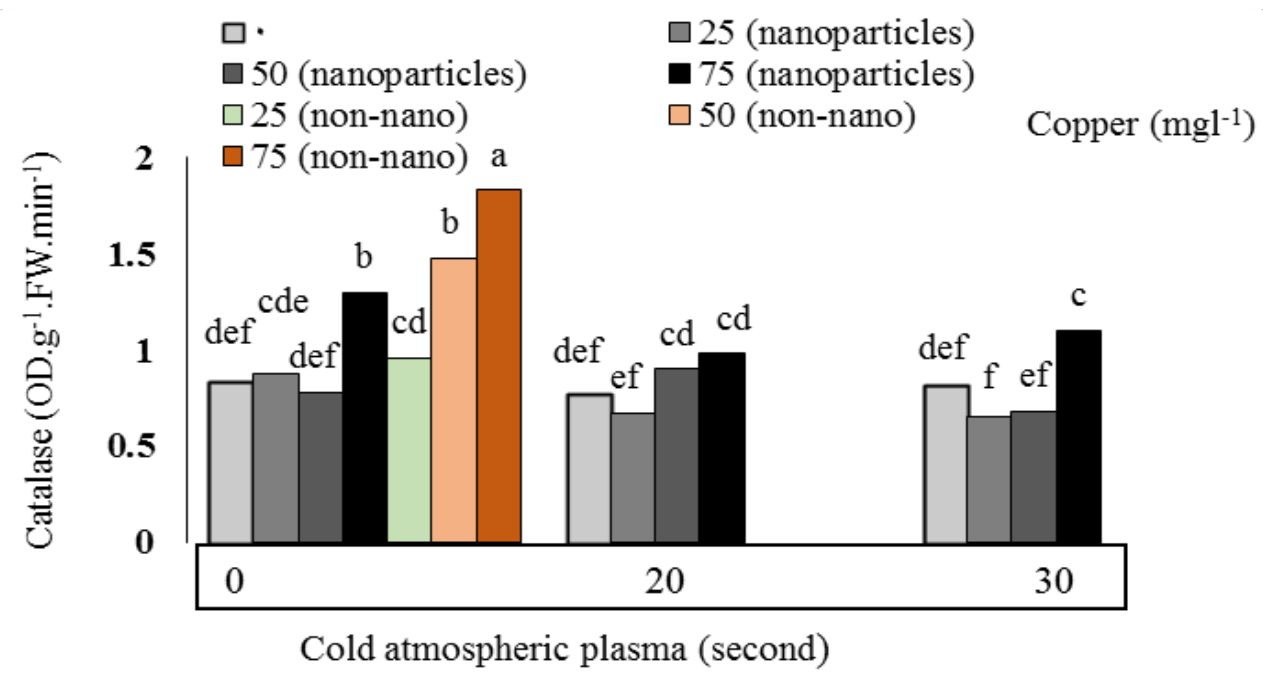

Figure 3. Investigating the activity of catalase enzyme under various levels of CAP and copper

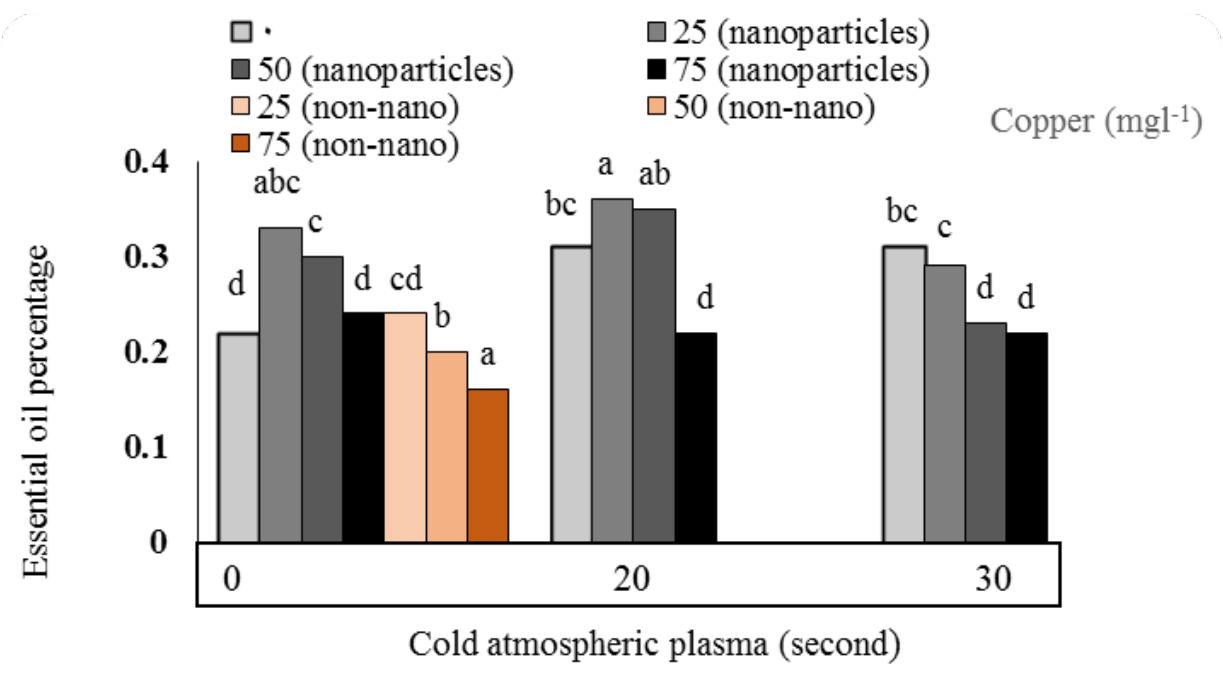

Figure 4. Investigating essential oil percentage under the influence of various levels of CAP and copper 
Table 1. Analysis of variance of the effects of $\mathrm{CN}$ and CAP on vegetative and biochemical indices of Dracocephalum moldavica L.

\begin{tabular}{|c|c|c|c|c|c|c|c|c|c|}
\hline $\begin{array}{c}\text { Sources of } \\
\text { changes }\end{array}$ & df & Flavonoid & $\begin{array}{c}\text { P- } \\
\text { Value }\end{array}$ & Catalase & $\begin{array}{c}\text { P- } \\
\text { Value }\end{array}$ & Peroxidase & $\begin{array}{c}\text { P- } \\
\text { Value }\end{array}$ & $\begin{array}{c}\text { Essential } \\
\text { oil } \\
\text { percentage }\end{array}$ & P-Value \\
\hline $\begin{array}{c}\text { Cold } \\
\text { atmospheric } \\
\text { plasma (a) }\end{array}$ & 2 & $0.13^{* *}$ & 0.002 & $0.09^{*}$ & 0.01 & $0.008^{*}$ & 0.02 & $0.01^{* *}$ & 0.006 \\
\hline $\begin{array}{c}\text { Copper } \\
\text { nanoparticles } \\
\text { (b) }\end{array}$ & 6 & $0.35^{* *}$ & 0.001 & $0.7^{* *}$ & 0.002 & $0.06^{* *}$ & 0.003 & $0.02^{* *}$ & 0.001 \\
\hline $\mathrm{a}^{* b}$ & 6 & $0.07^{* *}$ & 0.001 & $0.05^{*}$ & 0.04 & $0.003^{\text {ns }}$ & 0.1 & $0.006^{* *}$ & 0.001 \\
\hline Error & 45 & 0.01 & - & 0.02 & - & 0.002 & & 0.001 & 12.03 \\
\hline$\% \mathrm{CV}$ & & 9.9 & - & 13.77 & & 16.24 & & \\
\hline
\end{tabular}

$*$ and $* *$ mean significant effect at the probability level of 5\% and 1\% respectively; ns means non-significant effect.

Table 2. Comparison of the means, the effect of CAP on vegetative and biochemical indices of Dracocephalum moldavica $\mathrm{L}$.

\begin{tabular}{|c|c|c|c|c|c|c|c|c|}
\hline $\begin{array}{c}\text { Cold } \\
\text { atmospheric } \\
\text { plasma } \\
(\mathrm{s})\end{array}$ & $\begin{array}{c}\text { Flavonoid } \\
\text { (Absorbance g- } \\
1 \mathrm{FW})\end{array}$ & $\begin{array}{c}\text { P- } \\
\text { Value }\end{array}$ & $\begin{array}{c}\text { Catalase } \\
\text { (OD.g- } \\
1 . \text { FW.min- } \\
1)\end{array}$ & $\begin{array}{c}\text { P- } \\
\text { Value }\end{array}$ & $\begin{array}{c}\text { Peroxidase } \\
\text { (OD.g- } \\
1 . \text { FW/min- } \\
1)\end{array}$ & $\begin{array}{c}\text { P- } \\
\text { Value }\end{array}$ & $\begin{array}{c}\text { Essential } \\
\text { oil } \\
\text { percentage }\end{array}$ & $\begin{array}{c}\text { P- } \\
\text { Value }\end{array}$ \\
\hline 0 & $1.22 \mathrm{a}$ & 0.7 & $1.15 \mathrm{a}$ & 0.3 & $0.33 \mathrm{a}$ & 0.4 & $0.24 \mathrm{c}$ & 0.07 \\
\hline 20 & $0.91 \mathrm{~b}$ & 0.4 & $0.83 \mathrm{~b}$ & 0.2 & $0.24 \mathrm{~b}$ & 0.2 & $0.31 \mathrm{a}$ & 0.1 \\
\hline 30 & $0.93 \mathrm{~b}$ & 0.5 & $0.81 \mathrm{~b}$ & 0.2 & $0.22 \mathrm{~b}$ & 0.2 & $0.26 \mathrm{~b}$ & 0.09 \\
\hline
\end{tabular}

In each column, the means with common letters have no statistically significant difference at the probability level of $5 \%$ in the Duncan test.

Table 3. Comparison of the mean effect of CNon vegetative and biochemical indices of Dracocephalum moldavica L.

\begin{tabular}{|c|c|c|c|c|c|c|c|c|}
\hline $\begin{array}{c}\text { Copper } \\
\text { (mgl-1) }\end{array}$ & $\begin{array}{c}\text { Flavonoid } \\
\text { Absorbance } \\
\text { g-1FW) }\end{array}$ & $\begin{array}{c}\text { P- } \\
\text { value }\end{array}$ & $\begin{array}{c}\text { Catalase } \\
\text { (OD.g- } \\
1 . \text { FW.min- } \\
1 \text { ) }\end{array}$ & $\begin{array}{c}\text { P- } \\
\text { value }\end{array}$ & $\begin{array}{c}\text { Peroxidase } \\
\text { (OD.g- } \\
1 . \text { FW/min- } \\
1)\end{array}$ & $\begin{array}{c}\text { P- } \\
\text { value }\end{array}$ & $\begin{array}{c}\text { Essential } \\
\text { oil } \\
\text { percentage }\end{array}$ & P-value \\
\hline 0 & $1.13 \mathrm{c}$ & 0.2 & $0.84 \mathrm{de}$ & 0.3 & $0.22 \mathrm{de}$ & 0.1 & $0.28 \mathrm{~b}$ & 0.1 \\
\hline 25 (non-nano) & $1.04 \mathrm{~cd}$ & 0.2 & $0.96 \mathrm{~d}$ & 0.2 & $0.27 \mathrm{~d}$ & 0.1 & $0.24 \mathrm{c}$ & 0.1 \\
\hline 50 (non-nano) & $1.52 \mathrm{~b}$ & 0.4 & $1.48 \mathrm{~b}$ & 0.1 & $0.43 \mathrm{~b}$ & 0.08 & $0.2 \mathrm{c}$ & 0.1 \\
\hline 75 (non-nano) & $1.66 \mathrm{a}$ & 0.5 & $1.83 \mathrm{a}$ & 0.08 & $0.52 \mathrm{a}$ & 0.06 & $0.16 \mathrm{~d}$ & 0.08 \\
\hline 25 (nano) & $0.91 \mathrm{ef}$ & 0.1 & $0.73 \mathrm{e}$ & 0.4 & $0.2 \mathrm{e}$ & 0.1 & $0.33 \mathrm{a}$ & 0.2 \\
\hline 50 (nano) & $0.84 \mathrm{f}$ & 0.1 & $0.78 \mathrm{e}$ & 0.4 & $0.22 \mathrm{de}$ & 0.1 & $0.29 \mathrm{ab}$ & 0.2 \\
\hline 75 (nano) & $1.01 \mathrm{de}$ & 0.2 & $1.12 \mathrm{c}$ & 0.1 & $0.33 \mathrm{c}$ & 0.09 & $0.22 \mathrm{c}$ & 0.1 \\
\hline
\end{tabular}

In each column, the means with common letters have no statistically significant difference at the probability level of $5 \%$ in the Duncan test. 
- CAP was associated with a decrease in flavonoid. The CAP treatments of 20 and $30 \mathrm{~s}$ decreased flavonoid by $25.41 \%$ and $23.77 \%$, respectively (Table 2 ).

- $\mathrm{CN}$ was also associated with a reduction in flavonoid, and the most significant reduction was observed to be $25.66 \%$ in the $50 \mathrm{mgl}^{-1} \mathrm{CN}$ treatment.

- The $25 \mathrm{mgl}^{-1} \mathrm{NNC}$ treatment decreased flavonoid by $7.96 \%$. But as its concentration increased to 50 and $75 \mathrm{mgl}^{-1}$, flavonoid significantly was increased by 34.51 and $46.9 \%$, respectively (Table 3 ).

- The combined use of CAP and CN also significantly decreased total flavonoid content. The highest flavonoid level was observed in the absence of CAP and presence of the 50 and $75 \mathrm{mgl}^{-1} \mathrm{NNC}$ with the amounts of 1.52 and 1.66 absorbed in the wet weight.

- The lowest flavonoid level was in CAP of $30 \mathrm{~s}$ combined with $\mathrm{CN}$ of $50 \mathrm{mgl}^{-1}$ with the amount of .76 absorbed in the wet weight (Fig. 2).

\section{Activity of catalase and peroxidase enzymes}

The effects of CAP and CN and their interaction on the catalase enzyme activity were significant $(\mathrm{p}<$ $0.05)$ (Table 1). Besides, CAP $(\mathrm{p}<0.05)$ and $\mathrm{CN}(\mathrm{p}$ $<0.01$ ) exerted a significant effect on the peroxidase enzyme activity, but their interaction effect was not statistically significant $(\mathrm{p}>0.05)$.

1. The application of CAP caused a decrease in the activity of catalase and peroxidase enzymes. That is, the CAP treatments 20 and 30 s lessened the activity of catalase enzyme by 27.83 and $29.57 \%$ and also decreased the activity of peroxidase enzyme by 27.27 and $33.33 \%$, respectively (Table 2 ), although there was no significant difference between CAP treatments of 20 and $30 \mathrm{~s}$.

2. The 25 and $50 \mathrm{mgl}^{-1} \mathrm{CN}$ treatments respectively reduced the activity of catalase enzyme by $9.88 \%$ and $3.7 \%$, while the $75 \mathrm{mgl}^{-1} \mathrm{CN}$ treatment increased the activity of catalase enzyme by $38.27 \%$.

3. The 25, 50 and $75 \mathrm{mgl}^{-1} \mathrm{NNC}$ treatments showed an increase in the activity of catalase enzyme by $18.52 \%, 82.72 \%$ and $125.93 \%$, respectively. The 75 $\mathrm{mgl}^{-1} \mathrm{CN}$ treatment increased the activity of peroxidase enzyme by $50 \%$, but the presence of 25 and $50 \mathrm{mgl}^{-1} \mathrm{CN}$ made no significant difference.

4. The NNC treatments also increased the activity of the peroxidase, with the highest increase to be $136.36 \%$ by $75 \mathrm{mgl}^{-1}$ NNC (Table 3 ). The highest activity of the catalase with the amount of 1.83 absorbed in the wet weight per minute was associated to the absence of CPA and presence of $75 \mathrm{mgl}^{-1}$ $\mathrm{NNC}$, and the lowest activity of the catalase with the amount of 0.65 absorbed in the wet weight per minute was connected with the application of CPA for $30 \mathrm{~s}$ and the presence of $25 \mathrm{mgl}^{-1} \mathrm{CN}$ (Fig. 3).

\section{Essential Oil Percentage}

The results of ANOVA, as indicated in Table 1, showed that the effects of CAP, CN and their interaction on the essential oil percentage were significant $(\mathrm{p}<0.01)$.

1. The CAP treatment of $20 \mathrm{~s}$ increased the essential oil percentage by $29.17 \%$ (Table 2 ).

2. The $25 \mathrm{mgl}^{-1} \mathrm{CN}$ enhanced the essential oil percentage by $17.86 \%$, the $75 \mathrm{mgl}^{-1} \mathrm{CN}$ indicated a reduction of $21.43 \%$, and $50 \mathrm{mgl}^{-1} \mathrm{CN}$ made no significant difference.

3. All NNC treatments were associated with a decrease in the essential oil percentage. The NNC treatments of 25,50 and $75 \mathrm{mgl}^{-1}$ lessened the essential oil percentage by $14.29 \%, 28.57 \%$ and $42.86 \%$, respectively (Table 3 ).

4. The maximum essential oil percentage was observed to be $.36 \%$ in the CAP treatment of $20 \mathrm{~s}$ combined with $25 \mathrm{mgl}^{-1} \mathrm{CN}$, while its minimum was $0.16 \%$ in the absence of the CAP and presence of 75 $\mathrm{mgl}^{-1} \mathrm{NNC}$ (Fig. 4).

\section{DISCUSSION}

Plants have important roles in ecological stability of ecosystems, while the impact of nanoparticles upon them is not well known, especially for their effects of biochemical compounds in economical aromatic plants (Zuverza-Mena et al., 2017). Several studies have shown that the nanoparticles may have both negative and positive impacts on different plant species, depending on size, concentration and shape of nanoparticles (Costa \& Sharma, 2016; Wang et al., 2016; Tripathi et al., 2017). In this study, for the first time we investigated the effects of different doses of copper nanoparticles along with cold plasma atmospheric treatment on the biochemical compounds of $D$. moldavica $\mathrm{L}$.

Our results showed that copper nanoparticles with 25,50 and $75 \mathrm{mgl}^{-1}$ doses significantly increased the catalase and peroxidase activity and led to increase the essential oil contents.

The copper increases the activity of some enzymes, the photosynthesis concentration, the durability of the leaf surface, and thus the photosynthesis amount of plant, resulting in plant growth (Bauder \& Waskom, 2003). Flavonoids and phenolic compounds are secondary metabolites and have protective and antioxidant roles (Posmyk et al., 2007). In this regard has been proven that exposure of plants to high level of heavy metals can highly active phenolic compounds and flavonoids and protect the plants against toxicity (Dai et al., 2006; Posmyk et al., 2009). 
The toxic effects of heavy metals are due to the production of free radicals. In high plants, heavy metals, such as copper, induce the production of superoxide radical, hydrogen peroxide, hydroxyl and oxygen alone (Tiwari et al., 2008). ROS can quickly target all types of biological molecules, such as nucleic acids, proteins, amino acids and lipids, which leads to unrecoverable metabolic deficiency and ultimately cell death (Pandey et al., 2009; Wang et al., 2009). By increasing the level of ROS in the cells, the activities of the antioxidant enzymes increases (Pandey et al., 2009; Posmyk et al., 2009). In many plant species, the increase in the absorption of heavy metals, such as copper, induces a very high increase in the peroxidase activity and causes changes in the quality of its isoenzymes (Posmyk et al., 2009). On the other hand, the increase in the activity of peroxidase, as the main and key enzyme, in heavy metal stresses has been proven in such a way that this enzyme is known as stress markers in heavy metal stress (Choudhary et al., 2007).

In general, the production of essential oil is due to a set of physiological and morphological processes. In this regard, environmental factors, including nutrients such as copper have a significant effect on the production of essential oil.

Copper as a low-consumption element plays a very important role in the growth and development of essential oil from the medicinal plants. This element at low levels increases metabolic and physiological activities, photosynthesis and respiration, the energy required for biosynthesis of terpene compounds, leaf area and the number of essential oil oil-secreting glands. Furthermore, high levels of this element reduce essential oil percentage due to the negative effects on metabolic and physiological activities (Pande et al., 2007; Street, 2012).

In conclusion, our study showed positive impacts of copper nanoparticles in interaction with cold plasma atmospheric on D. moldavica biochemical compounds and enzymatic activity. The literature reviews in this area few and it is necessary to conduct more detailed researches to understand molecular mechanism of plant nanoparticles interaction. Our results showed beneficial impacts on copper nanoparticles, but the mechanisms at large extent are not understood, and our results are in primitive stages. Therefore, we recommend for future studies on the effects on nanoparticles before bringing the nanoparticles to the field.

\section{ACKNOWLEDGEMENT}

The authors wish to thank all laboratory staff who participated in this study. This work received no financial support.

\section{REFERENCES}

Abd El-Baky, H. \& El-Baroty, G. 2008. Chemical and biological evaluation of the essential oil of Egyptian moldavian balm (Dracocephalum moldavica L.). International Journal of Integrative Biology 3: 202-208.

Aebi, H. 1984. Catalase in vitro. Methods Enzymology 105: 121-126.

Asgari-Targhi, G., Iranbakhsh, A. \& Ardebili, Z.O. 2018. Potential benefits and phytotoxicity of bulk and nano-chitosan on the growth, morphogenesis, physiology, and micropropagation of Capsicum annuum. Plant Physiol. Biochem. 127: 393-402.

Baruah, S. \& Dutta, J. 2009. Nanotechnology applications in pollution sensing. and degradation in agriculture: a review. Environm. Chem. Lett. 7: 191-204.

Bauder, T. \& R, Waskom. 2003. Best management practices for colorado corn. Colorado State Univ. Coop. Ext. Bul. Xcm 574a. Fort Collins, Co. 87p.

Bormashenko, E., Shapira, Y., Grynyov, R., Whyman, G., Bormashenko, Y. \& Drori, E. 2015. Interaction of cold radiofrequency plasma with seeds of beans (Phaseolus vulgaris). J. Exp. Botany 66: 4013-4021.

Chandra, S., Kumar, A. \& Tomar, P. K. 2014. Synthesis and characterization of copper nanoparticles by reducing agent. J. Saudi Chem. Soci. 18: 149-153.

Choudhary, M., Jetley, U. K., Khan, M. A., Zutshi, S. \& Fatma, T. 2007. Effect of heavy metal stress on proline, malondialdehyde, and superoxide dismutase activity in the cyanobacterium spirulina platensis-s5. Ecotoxicol. Environm. Safety 66: 204-209.

Costa, M.V.J. \& Sharma, P.K. 2016. Effect of copper oxide nanoparticles on growth, morphology, photosynthesis, and antioxidant response in Oryza sativa. Photosynthetica 54: 110-119.

Dai, L.P., Xiong, Z.T., Huang, Y. \& Li, M.J. 2006. Cadmium-induced changes in pigments, total phenolics, and phenylalanine ammonia-lyase activity in fronds of azolla imbricata. Environm. Toxicol. Journal 21: 505512.

Fernández, A. \& Thompson, A. 2012. The inactivation of salmonella by cold atmospheric plasma treatment. Food Res. Inter. 45: 678-684.

Haddadian K., Iranbakhsh, A., Khavary Nejad, R.A. \& Ghorannevi, M. 2017. Copper nanoparticles together with cold atmospheric plasma improves the growth and physiological indices of Dracocephalum moldavica in hydroponic system. J. Exp. Biol.7: 130-139

Hafeez, A., Razzaq, A., Mahmood, T. \& Jhanzab, H.M. 2015. Potential of copper nanoparticles to increase growth and yield of wheat. J. Nanosci. Adv. Technol. 1: 6-11.

Hussein, M.S., El-sherbeny, S.E., Khalil, M.Y. \& Naguib, N.Y., Aly, S.M. 2006 . Growth characters and chemical constituents of Dracocephalum moldavica L. plants in relation to compost fertilizer and planting distance. Scientia Horticulturae 108: 322-331.

Jiang, J., Lu, Y., Li, Y., Li, L., He, X., Shao, H. \& Dong, Y. 2014 . Effect of seed treatment by cold plasma on the resistance of tomato to ralstonia solanacearum. Plos One 9: E97753. 
Kar, M. \& Mishra, D. 1976. Catalase, peroxidase, and polyphenoloxidase activities during rice leaf senescence. Plant Physiol. 57: 315-319.

Manikandan, R., Ezhili, N. \& Venkatachalam, P. 2016. Phosphorus supplementation alleviation of the cadmiuminduced toxicity by modulating oxidative stress mechanisms in vetiver grass [Chrysopogon Zizanioides (L.) Roberty]. J. Environ. Engin. 142: C4016003.

Manikandan, R., Sahi, S. \& Venkatachalam, P. 2015. Impact assessment of mercury accumulation and biochemical and molecular response of mentha arvensis: a potential hyperaccumulator plant. Sci. World J. 2015: 715217.

Meiqiang, Y., H. Mingjing., Buzhou, M. \& Tengcai, M. 2005. Stimulating effects of seed treatment by magnetized plasma on tomato growth and yield. Plasma Scie. Tech. 7: 3143-3147

Menard, A., Drobne, D. \& Jemec, A. 2011. Ecotoxicity of nanosized Tio2. Review of in vivo data. Environmental Pollution 159: 677-684.

Mihai, A., Dobrin, D., Magureanu, M. \& Popa, M. 2014. Positive effect of non-thermal plasma treatment on radish seeds. Romanian Rep. Physics 66: 1110-1117.

Monica, R.C. \& Cremonini, R. 2009. Nanoparticles and higher plants. Caryologia 62: 161-165.

Monreal, C. 2010. In summary of information currently provided to MRI concerning applications for Round 5 of the Ontario Research Fund-Research Excellence Program, pp.12-13

Olszewska, M., Grzegorczyk, S., Alberski, J., BaluchMalecka, A. \& Kozikowski, A. 2008. Effect of copper deficiency on gas exchange parameters, leaf greenness [spad] and yield of perennial ryegrass [Lolium perenne 1.] and orchard grass [Dactylis glomerata 1.]. Journal of Elementology 13: 597-604.

Pande, P., Anwar, M., Chand, S., Yadav, V.K. \& Patra, D. 2007. Optimal level of iron and zinc in relation to its influence on herb yield and production of essential oil in menthol mint. Communications in Soil Science and Plant Analysis 38: 561-578.

Pandey, N., Pathak, G.C., Pandey, D.K. \& Pandey, R. 2009. Heavy Metals, Co, Ni, Cu, Zn And Cd, produce oxidative damage and evoke differential antioxidant responses in spinach. Brazilian J. Plant Physiol. 21: 103111.

Posmyk, M., Janas, K. \& Kontek, R. 2007. Effect of anthocyanin-rich red cabbage extract on cytological injury induced by copper stress in plant and animal tissues. Ochrona Środowiska I Zasobów Naturalnych. 33: 50-56.

Posmyk, M., Kontek, R. \& Janas, K. 2009. Antioxidant enzymes activity and phenolic compounds content in red cabbage seedlings exposed to copper stress. Ecotoxic. Environm. Safety 72: 596-602.
Rico, C.M., Majumdar, S., Duarte-Gardea, M., PeraltaVidea, J.R. \& Gardea-Torresdey, J.L. 2011. Interaction of nanoparticles with edible plants and their possible implications in the food chain. J. Agricul. Food Chem. 59: 3485-3498.

Shalaby, T.A., Bayoumi, Y., Abdalla, N., Taha, H., Alshaal, T., Shehata, S., Amer, M., DomokosSzabolcsy, É. \& El-Ramady, H. 2016. Nanoparticles, soils, plants and sustainable agriculture. Nanosci. Food Agricult. 1: 283-312.

Sivachandiran, L. \& Khacef, A. 2017. Enhanced seed germination and plant growth by atmospheric pressure cold air plasma: combined effect of seed and water treatment. RSC Advances 7: 1822-1832.

Song, G., Hou, W., Gao, Y., Wang, Y., Lin, L., Zhang, Z., Niu, Q., Ma, R., Mu, L. \& Wang, H. 2016. Effects of Cuo nanoparticles on Lemna minor. Botanical Studies 57: $1-8$

Street, R. 2012. Heavy metals in medicinal plant productsan african perspective. South African J. Bot. 82: 67-74.

Tiwari, K., Dwivedi, S., Mishra, S., Srivastava, S., Tripathi, R., Singh, N. \& Chakraborty, S. 2008. Phytoremediation efficiency of portulaca tuberosa rox and portulaca oleracea 1. Naturally growing in an industrial effluent irrigated area in vadodra, gujrat, india. Environmental Monitoring and Assessment 147: 15-22

Tripathi, D.K., Singh, S., Singh, S., Srivastava, P.K., Singh, V. P. \& Singh S. 2017. Nitric oxide alleviates silver nanoparticles (agnps)-induced phytotoxicity in Pisum sativum seedlings. Plant Physiol. Biochem.110: 167-177.

Wang, F., Zeng, B., Sun, Z. \& Zhu, C. 2009. Relationship between proline and hg 2+-induced oxidative stress in a tolerant rice mutant. Arch. Environ. Contam. Toxicol. 56: 723-731.

Wang, M.H., Misra, R.P., Giraldo, J.P., Kwak, S.Y., Son, Y. \& Landry, M.P. 2016. Lipid exchange envelope penetration (LEEP) of nanoparticles for plant engineering: a universal localization mechanism. Nano Lett. 16: 1161-1172.

Wu, Z., Chi, L., Bian, S. \& Xu, K. 2007. Effects of plasma treatment on maize seeding resistance. J. Maize Sci. 15: 111-113.

Zuverza-Mena N., Armendariz, R., Peralta-Videa, J.R. \& Gardea-Torresdey, J.L. 2017. Effects of silver nanoparticles on radish sprouts: root growth reduction and modifications in the nutritional value. Front. Plant Sci. 7: 1-11

Zhu, H., Han, J., Xiao, Q. \& Jin, Y. 2008. Uptake, translocation, and accumulation of manufactured iron oxide nanoparticles by pumpkin plants. Journal of Environmental Monitoring 10: 713-717.

How to cite this article:

Haddadian, K., Iranbakhsh, A., Khavari Nejad, R.A. \& Ghorannevis, M. 2021. The effects of copper nanoparticles and cold atmospheric plasma on biochemical indices of Dracocephalum moldavica. Nova Biologica Reperta 7: 411-418. 